Vol. 02, No. 02: March (2017)
Open access available at http://journalofbusiness.us

\title{
Analysis of Credit Risk, Efficiency, Liquidity, and Profitability of Selected Non-Bank Financial Institution: An Empirical Study
}

\author{
Sabrina Akhtera*, Jewel Kumar Royb \\ a Senior Lecturer, Department of Business Administration, Faculty of Business \& Economics, Daffodil International University, Dhaka, \\ Bangladesh. Cell: 01712136014. \\ bLecturer, Department of Finance and Banking, Faculty of Business Administration, JatiyaKabiKaziNazrul Islam University (JKKNIU), \\ Trishal, Mymensingh-2220, Bangladesh. Cell: 01924337923, E-mail: roy.jkkniu@gmail.com. \\ *Corresponding author's e-mail address: sabrina@daffodilvarsity.edu.bd
}

\section{A R T I C LE IN F O}

Received: 14-03-2017

Accepted: 18-03-2017

Available online: 19-03-2017

\section{Keywords:}

Loan to Deposit Ratio;

Net Interest Margin;

Non-Bank Financial Institutions;

Non-Performing Loans;

Return on Assets.

JEL Classification:

F34; G21; G23; G28; G32.

\section{A B S T R A C T}

Financial Institutes are the lifeblood of the financial system of any country that plays an intermediary between the surplus and deficit unit of any society. So the efficiency and performance of a financial institution is the indication of sound financial system. In this study the authors are trying to analyze the factors such as credit risk, efficiency, liquidity, and profitability; which affect the performance of non-bank financial institutions. The methods used are descriptive with secondary data from financial statements of Non-Bank Financial Institutions from 2010 to 2015. Linear regressions, ANOVA, hypothesis testing while using F-test to examine the effect of variables simultaneously with a significance level of $5 \%$. Based on the results it is concluded that partial NPM and ROA have positive and significant effects on LDR. NPL has a negative effect of loan to deposit ratio. The amount of the contribution or influence variable of NIM, OPM, NPM, ROA, ROE and NPL to the dependent variable of LDR is $87.45 \%$ while the remaining $12.55 \%$ thought to be influenced by other variables not examined in this study.

This is an open access article under the terms of the Creative Commons Attribution License 4.0, which allows use, distribution and reproduction in any medium, provided the original work is properly cited.

\section{Preamble}

Given the difficult nature of financial intermediaries in Third World nations, the financial industry in Bangladesh is not atypical. In reality, financial industry faces a particularly challenging environment in Bangladesh. Financial activity is essential in ensuring that the financial system and the economy run smoothly and efficiently(Mishkin and Eakins, 2006). The collective effects of financial intermediation, which are the externality and inter-sectoral factor productivity differential effects on economic growth are significantly positive and do not appearto depend on the stage of economic development attained (M.O. Odedokun, 1998).The purpose of this study is to measure the performance of selected non-bank financial institutions after analyzing of credit risk, efficiency, liquidity, and profitability. The non-bank financial institution plays a vital role as the financial institutions in the economy of a country. Bank facilitates the interests of savers by borrowers through products and financial services it offers. On the other side, non-bank financial institutions play an important role in the stock exchange of the country. 34 NBFIs (3 government-owned, 21 privately-owned and 10 joint ventures with foreign companies) are operating their business (in total 211 branches) in Bangladesh. The key funding sources of NBFIs are capital, call money borrowing, credit facilities from banks and other NBFIs, term deposits and securitization. The sector's nonperforming loans compared to total loans rose 3.6\% point's year-on-year to 8.9\% in 2015.Loan lossprovision 
amounting to Tk. 1,420 crore was preserved by NBFIs against the requirement of Tk. 1,980 crore in 2015 . A coverage ratio of only $35.5 \%$ of non-performing loans and leases, down 20\% points from 2014(Rahman, 2016).

Non-performing loans refer to those financial assets from which banks no longer receive interest or installment payments as scheduled. It is a very critical but frequent issue in bank fund management and the present situation of NPLs in Bangladesh is a topic of great concern. It can bring down investors' confidence and if created by the borrowers willingly and left unresolved might act as a contagious financial malaise by driving good borrowers out of the financial market. The volume of default loans of listed banks in Dhaka Stock Exchange has been increasing at an alarming rate. It is not a new issue but the tendency of fraud, embezzlement and loan default is in a serious situation in recent years due to excessive political interference and illegal interruption of the concerns. The amount of total non-performing loans in the banking system of Bangladesh was Tk. 546.57 billion till June 2015, which was Tk. 427.3 billion in 2012 and 200.1 billion in 2006. The amount more than doubled within 10 years. For last 8 years, loan default as a percentage of outstanding loans in state-owned commercial banks was $50 \%$ or above where Private commercial banks and foreign commercial banks and hold maximum 5-10\% amount of the total. A high volume of non-performing loans cannot be a boon for the economy. If the invested funds in an economy are not recovered, it limits the recycling of the funds is reduced by a number of classified loans which may lead to economic stagnation. One commonly used indicator to measure the implementation of non-banking financial institution intermediation is the ratio of loans to deposits or loans to deposits ratio (LDR) (Haruna, 2011; Buchory, 2006). Non-Performing Loans affects banks' profitability adversely because of the provision of classified loans and consequent write-off as bad debts reduce thereturn on investment and disturb the capital adequacy ratio. It also increases the cost of capital, widens assets and liability imbalance and upsets the economic value additions ${ }^{1}$ by banks. The study is conducted to find out the effect of Credit risk, NPL, Liquidity and profitability on the performance of selected Non-Bank Financial Institutions (NBFIs) in Bangladesh. To fulfill this objective the researchers are trying to find the effect of profit and nonperforming loan on loan and deposit.

\section{Literature review}

The lending decision of a bank is very important because it determines the future profitability and performance of the bank. Recently banks are becoming more and more conscious in customer selection to avoid the negative impact of thebad loan or non-performing loan. The issue of non-performing loans has gained increasing attentions in the last few decades. Amounts of bad loans are alarmingly increasing in not only the developing and underdeveloped countries but also in Non-performing loans are regressed on three sets of factors in terms of credit, banks size induced risk preference and macroeconomic shocks. The panel regression models show the terms of credit variables to be significant. The estimated coefficient on changes in thecost of credit because of expectation of higher interest rate is positive. On the contrary, thehorizon of maturity of credit, better credit culture, and favorable macroeconomic and business conditions decrease the non-performing loans (Ranjan and Sarat, 2003).

Pre-election has an influencing power in the regulatory side of the financial sector. The Government and Bangladesh Bank appear to be under pressure from certain quarters due to this. This becomes evident with the relaxation of the guidelines issued by Bangladesh Bank on defaulters accessing fresh loans. This is clearly not an easy environment to operate in and specific steps should be taken to prevent the situation from further deteriorating and undermining the banking sector (Wallich, 2006).

The indicators commonly used to measure the extent of intermediation by the banking system have been implemented, namely by looking at the ratio of loans to deposits known as loans to deposits ratio. An indicator to measure the workings of the banking intermediation function is to look at the loan to deposit ratio. LDR ratio reflects the ability of banks to extend credit and collect public funds. The higher this ratio is, the better it means that the bank could carry out intermediation function optimally. Vice versa, the lower this ratio means the bank in carrying out its intermediary function is not optimal (Buchory, 2014).

The presence of an alarming amount of non-performing loans both in the Nationalized Commercial Banks (NCBs) and in the Development Financial Institutions (DFIs), along with maintenance of inadequate loan loss provisions, diminishes the overall credit quality of Bangladesh. Poor enforcement of laws relating to thesettlement of NPLs, followed by insufficient debt recovery measures on the part of the banks, has also aggravated the financial malaise (Adhikari, 2007).

${ }^{1}$ Economic Value Additions (EVA) is equal to the net operating profit minus cost of capital. 
In making lending decisions, banks are assumed to react differently to NPL ratios above or below a threshold. With non-performing loans above the threshold has an adverse effect on lending. Bank's lending behavior could restrain economic activity, especially in periods of stress when non-performing loans are high (Tracey, 2011).

Non-performing loans are increasing due to lack of risk management, which threatens the profitability of banks. This study provides a suggestion that banking sector can avoid their non-performing loans by adopting methods suggested by the central bank of theperspective country (Haneef and Riaz, 2012).

All the selected independent variables (real GDP per capita, inflation, and total loans as independent variables) have asignificant impact on the depended variable (non-performing loan ratio), however, values of coefficients are not much high. Banks should control and amend their credit advancement policy with respect to mentioned variables to have lower non-performing loan ratio (Saba, Kouser and Azeem 2012);

To analyze the factors that affect the implementation of banking intermediation include capital, net interest margin, credit risk and profitability. The methods used are descriptive with secondary data from financial statements all over 26 Indonesian Regional Development Banks as a research object's units. Data analysis technique is the multiple linear regressions, hypothesis testing while using $\mathrm{t}$ - test to examine the effect of partial variables and F-test to examine the effect of variables simultaneously with a significance level of $5 \%$. Based on the results it is concluded that partial NIM and ROA have positive and significant effects on LDR. NPL has a positive effect but no significant effect to LDR (Buchory, 2014).

The study will examine the efficiency, productivity, profitability, investment return and capital strength positively effect on liquidity and leverage. It will also analyze the asset management and asset quality negatively effect on liquidity and leverage. The study will take the sample size from the overall non-banking financial institutions which will reflect the current scenario of this industry.Based on the phenomenon above, indicates the performance of the Financial Institutions against the loan to debt ratio and non-performing loan ratio which are an extremely important measurement for this industry as well as the economy. The limitation of the study is not to justify with the returns of the NBFIs with Non-Performing Loans and show the effect on ARCH and GARCH model to measure the volatility of Banks by the time series data analysis. The further study will show the effect. The further study will also measure the overall Banking sector in Bangladesh where the Foreign Banks will be included.

\section{Research methodology}

In this study we have used secondary data for analysis and choose twelve leading non-bank financial institutions (NBFIs) from Bangladeshi market. They are: IDLC Finance Ltd, Lanka Bangla Finance Ltd, Prime Finance Ltd, Islami Finance Ltd, Delta Brac Housing Ltd, United Finance Ltd, IIDFC, Phonix Leasing Co Ltd, Bay Leasing Ltd, IPDC, Uttara Finance Ltd and Union Capital Ltd. For the study, data has been collected from the annual reports of the selected NBFIs from 2010 to 2015.The methods used in this research are descriptive method and verification method. Descriptive method is a method used to analyze data in a way to describe or depict the data that has been collected as is without intending to apply general conclusions or generalizations while the verification method is a method of research that aims to determine the relationship between two or more variables. This verification method is used to test the truth of a hypothesis. Influence or shape the causal relationship between variables X and Y can be known from the research method of verification.

\subsection{Type, data source, population, sample, and data collection methods}

Information related to NPLs, credit policy, recovery system, default rate are very much confidential to any Financial Institute. Secondary data has been used in preparing this research paper. The sources of data are Bangladesh Bank Library, Credit Information Bureau, Annual Reports of NBFIs, Articles and research papers from reputed journals.The collected data has been processed and analyzed both manually and with the help of electronic devices. A ratio analysis has done to find out the trend of loan to deposit, net interest margin, operating margin, net profit margin, return on asset, return on equity, non-performing loanofNBFIs for year 2010 to 2015. Four hypotheses have been tested with correlation, regression and ANOVA from EXCEL data analysis tools.

\subsection{Operational variables}

This study uses the independent variables, namely net interest margin, nonperforming loans, return on assets and the dependent variable is the implementation of function banking intermediation as measured by the loan to debt ratio. 


\begin{tabular}{lll}
\hline Category & Ratio Analysis & Variable \\
\hline Liquidity \& Leverage & Loan-Deposit Ratio & Dependent \\
$\begin{array}{l}\text { Efficiency \& Productivity \& Capital } \\
\text { Strength }\end{array}$ & Net Interest Margin & Independent \\
Profitability \& Investment Return & Operating Margin, Net Profit Margin, & Independent \\
& Return on Asset, Return on Equity & \\
Asset Management \& Asset Quality & Non-Performing Loan Ratio & Independent \\
\hline
\end{tabular}

Source: Author's compilation

\subsection{Analysis techniques data}

The data analysis technique used in this study is a linear regression and ANOVA test. First, it is tested to determine whether the assumptions of classical linear regression model doesn't have problem of normality, multicollinearity, heteroscedasticity and autocorrelation. If all of them were fulfilled means that the model has a decent analysis used.

\subsection{Hypothesis}

Based on the relationship between research objectives and theoretical framework to the formulation of the research problem, the hypothesis is as follows:

H1: Efficiency, Productivity and Capital Strength positively effect on Liquidity and Leverage.

H2: Profitability and Investment Return positively effect on Liquidity and Leverage.

H3: Asset Management and Asset Quality negatively effect on Liquidity and Leverage.

To examine the hypothesis was used T-test to determine statistical significance of the effect of independent variables on the dependent variable partially, F-test to determine the statistical significance of the coefficient multiple significance or F-test to determine significance of the independent variables on the dependent variable simultaneously. Data processing is done by using the Excel Data Analysis Tools. The regression equation used is as follows:

$\mathrm{Y}=\mathrm{a}+\beta \mathrm{X} 1+\beta \mathrm{X} 2+\beta \mathrm{X} 3+\beta \mathrm{X} 4+\beta \mathrm{X} 5+\beta \mathrm{X} 6+\mathrm{e}$

Whereas,

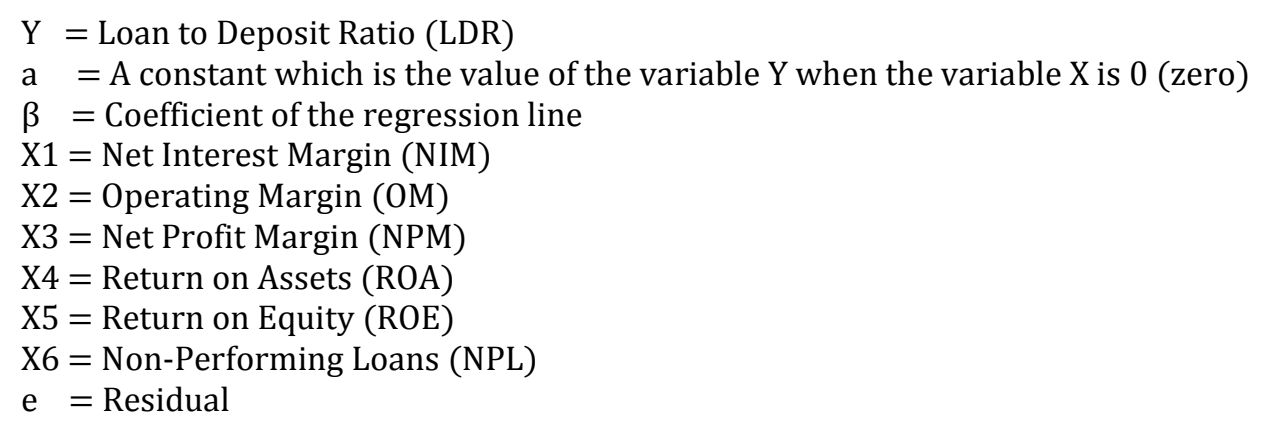

\section{4. $\quad$ Findings and discussion}

The statistical analysis of secondary data has been divided into four dimensions, i.e. descriptive, regression, ANOVA, Coefficients, and F-Test. Table 4.1 exhibit descriptive statistics of the explanatory variables for the selected NBFIs. The analyzed statistics figures show the mean, standard deviation, maximum and minimum values of the NBFIs.

This is the arithmetic mean across the observations. It is the most widely used measure of central tendency. It is commonly called the average. The mean is sensitive to extremely large or small values.The standard error gives some idea about the variability possible in the statistic.

Standard deviation is the square root of the variance. It measures the spread of a set of observations. The larger the standard deviation is, the more spread out the observations are. Here the largest standard deviation is foraloan to deposit ratio, which means it is mostly affected by other variables. The minimum, or smallest,thevalue of the variable is the Non-performing loan ratio and the maximum, or largest, value of the variable loan to deposit ratio. Which describes that the amount of NPL is smaller than LDR. 
Table 4.1: Descriptive statistics

\begin{tabular}{|c|c|c|c|c|c|c|c|}
\hline Statistical Tools & LDR & NIM & $\mathrm{OM}$ & NPM & $\mathrm{ROA}$ & ROE & NPL \\
\hline Mean & 1.67 & 0.34 & 0.31 & 0.17 & 0.02 & 0.19 & 0.11 \\
\hline Standard Error & 0.06 & 0.03 & 0.02 & 0.02 & 0.01 & 0.01 & 0.03 \\
\hline Standard Deviation & 0.48 & 0.26 & 0.15 & 0.13 & 0.08 & 0.12 & 0.22 \\
\hline Kurtosis & 2.59 & 20.16 & 1.72 & 3.18 & 29.99 & 1.97 & 8.09 \\
\hline Skewness & 1.57 & 4.04 & 0.70 & 0.60 & 4.95 & 1.33 & 3.03 \\
\hline Minimum & 1.14 & 0.02 & 0.10 & 0.27 & 0.11 & 0.03 & 0.01 \\
\hline Maximum & 3.46 & 1.70 & 0.75 & 0.56 & 0.53 & 0.59 & 1.00 \\
\hline Sum & 120.35 & 24.38 & 22.09 & 12.47 & 1.43 & 13.80 & 7.81 \\
\hline Count & 72.00 & 72.00 & 72.00 & 72.00 & 72.00 & 72.00 & 72.00 \\
\hline
\end{tabular}

Source: Author's calculation

Now, the researchers will like to present the regression results (Table 4.2) associated with the key performance indicators (the ratios). The R-square is certainly significant (87\%), so around $87 \%$ of the changes in the dependent variable can be explained by the regression.

Table 4.2: Regression statistics

\begin{tabular}{lrrrr}
\hline Multiple R & R Square & Adjusted R Square & Standard Error & Observations \\
\hline 0.935 & 0.875 & 0.848 & 0.648 & 72 \\
\hline
\end{tabular}

Source: Author's calculation

Table 4.3 shows the output of the ANOVA analysis and whether there is a statistically significant difference between group means. We can see that the significance value is 1.31 . Which is above the significant level 0.05 . Therefore there is no statistically significant relationship between the variables.

Table 4.3: ANOVA

\begin{tabular}{lrrrrr}
\hline & df & SS & MS & F & Significance F \\
\hline Regression & 7 & 190.116 & 27.159 & 64.748 & 1.317 \\
Residual & 65 & 27.265 & 0.4195 & & \\
Total & 72 & 217.381 & & & \\
\hline
\end{tabular}

Source: Author's calculation

From table 4.4 we know the actual multiple regression equation is $\mathrm{Y}=\mathrm{a}+\beta \mathrm{X} 1+\beta \mathrm{X} 2+\beta \mathrm{X} 3+\beta \mathrm{X} 4+\beta \mathrm{X} 5+\beta$ $\mathrm{X} 6+\mathrm{e}$. whereas, a denotes the constant, X1 is the slope or coefficient of Net Interest margin , X2 is the slope or coefficient of Operating Margin, X3 is the coefficient of Net Profit Margin \& X4 is the coefficient of Return on Asset, X5 is the coefficient of Return on Equity, X6 is the coefficient of Non-performing loans and $€$ is the error which accounts for the variability in Y that can't be explained by the linear effect of the 6 independent variables. This multiple regression equation reveals that Y (Loan to Deposit Ratio) is dependent variable. Net interest margin, Operating profit margin, Net Profit margin, Return on Asset, Return on Equity and Non-Performing Loan are the independent variables.

Refer to the Table no 4.4 the coefficient X1=0.1805 expresses that if the NIM increases by 1 percent, LDR will also be increased by $0.18 \%$ because of existing a positive relationship between LDR\&NIM along with the condition that the other things especially the other independent variables remain same. The coefficient X2= 4.1136 expresses that if the OPM increases by 1 percent, LDR will also be increased by $4.11 \%$ because of prevailing positive relationship between the loan deposit ratio \& operating profit margin along with the condition that the other things especially the other independent variables remain same. The coefficient X3= 0.9255 expresses that if the NPM increases by 1 percent, Net profit margin will also be decreased by $0.9255 \%$ which is not possible according to theory. The coefficient X4 and X5 $=1.9155$ and 0.7390 respectively expresses that if the ROA and ROE increases by 1 percent, LDR will also be increased by $1.9155 \%$ and $0.7390 \%$ because of prevailing positive relationship between the ROA and ROE with LDR along with the condition that the other things especially the other independent variables remain same.

Table 4.4: Coefficients

\begin{tabular}{lrrrrrrrr}
\hline Variables & Coefficients & $\begin{array}{r}\text { Standard } \\
\text { Error }\end{array}$ & t Stat & P-value & $\begin{array}{r}\text { Lower } \\
95 \%\end{array}$ & $\begin{array}{r}\text { Upper } \\
95 \%\end{array}$ & $\begin{array}{r}\text { Lower } \\
99.0 \%\end{array}$ & $\begin{array}{r}\text { Upper } \\
99.0 \%\end{array}$ \\
\hline NIM & & & & 0.539 & -0.403 & 0.764 & -0.594 & 0.955 \\
OM & 0.181 & 0.292 & 0.618 & 0.534 & 1.383 & 6.844 \\
NPM & 4.114 & 1.029 & 3.997 & 0.000 & 2.058 & 6.169 & 1.383 \\
ROA & -0.926 & 1.248 & -0.742 & 0.461 & -3.417 & 1.566 & -4.236 & 2.385 \\
\hline
\end{tabular}




\begin{tabular}{lllllrlrl}
\hline ROE & 0.739 & 0.694 & 1.064 & 0.291 & -0.648 & 2.126 & -1.103 & 2.581 \\
NPL & 1.434 & 0.562 & 2.549 & 0.013 & 0.311 & 2.557 & -0.059 & 2.926 \\
\hline SOHre:
\end{tabular}

Source: Author's Calculation

The F-test is used to determine whether a significant relationship exists between thedependent variable (LDR) and the set of all independent variables (NIM, OPM, NPM, ROA, ROE and NPL).

Table 4.5: F-Test

\begin{tabular}{lrrrrrrr}
\hline & LDR & NIM & OM & NPM & ROA & ROE & NPL \\
\hline Mean & 1.672 & 0.339 & 0.307 & 0.173 & 0.020 & 0.192 & 0.108 \\
Variance & 0.228 & 0.065 & 0.022 & 0.016 & 0.006 & 0.014 & 0.049 \\
Observations & 72.000 & 72.000 & 72.000 & 72.000 & 72.000 & 72.000 & 72.000 \\
Df & 71.000 & 71.000 & 71.000 & 71.000 & 71.000 & 71.000 & 71.000 \\
F & & 3.503 & 10.340 & 13.981 & 37.429 & 16.754 & 4.626 \\
P(F $<=$ f) one-tail & & 1.654 & 1.849 & 2.043 & 2.556 & 7.139 & 3.810 \\
F Critical one-tail & & 1.481 & 1.481 & 1.481 & 1.481 & 1.481 & 1.481 \\
\hline Source: Author's Cal
\end{tabular}

Source: Author's Calculation

We will refer to the F-test (Table 4.5) as the test for overall significance. The table shows that return on asset has the highest significant relationship with LDR.

\section{Policy implication}

After the analysis, we can conclude that there is a significant relationship exists between the loan to deposit ratio, net interest margin, operating margin, net profit margin, return on asset, return on equity, and nonperforming loan,although some of the results of statistical tools shows insignificant relationship between the dependent and independent variables.

The study indicates that the relationship between the efficiency, productivity, profitability, investment return and capital strength on liquidity and leverage has asignificant effect. It will also analyze the asset management and asset quality on liquidity and leverage has anadverse effect.

\section{Conclusion}

As lending is the most profitable investment for non-bank financial institution, non-performing loan has effect on profitability of the non-bank financial institution. In this study, we tried to show the impact of nonperforming loan on non-bank financial institution profitability. It's time to work with non-performing loan as the funds that are given to the borrowers as loans must be safe and are recovered and when due. Banks do business with depositor's money, if banks can't get depositors fund when they want, there might be a vulnerable situation in the industry. Public may lose confidence from the non-bank financial institution, which may create run on the non-bank financial institution.

The amount of the contribution or influence variable of NIM, OPM, NPM, ROA, ROE and NPLto the dependent variable of LDR is $87.45 \%$ while the remaining $12.55 \%$ thought to be influenced by other variables not examined in this study.As a result profitability of the non-bank financial institution can be negatively affected. The suggestions given above can be taken into consideration to reduce non-performing loan. Also as the mother bank and non-bank financial institution of the country, Bangladesh bank has some role to play to ensure sound environment in the banking and non-bank financial institution industry.

\section{References}

Adhikari B. K. (2007), "Nonperforming Loans in the Banking Sector of Bangladesh: Realities and Challenges", $B I B M$.

Buchory, H. A.(2006),“The Influence of Financial Intermediary Function Implementation, Risk Management Application and Bank Capital Structure on Banking Financial Performance" DisertasiFakultasEkonomi, UniversitasPadjadjaran Bandung.

Buchory, H. A. (2014), "Analysis of the Effect of Capital, Net Interest Margin, Credit Risk and Profitability in the Implementation of Banking Intermediation", European Journal of Business and Management, ISSN 22221905 (Paper), Vol.6, No.24, 2014.

Haneef, S., and Riaz, T. (2012), "Impact of Risk Management on Non-Performing Loans and Profitability of Banking Sector of Pakistan", International Journal of Business and Social Science, Vol. 3 No. 7. 
Haruna, Muhammad Auwalu, (2011)“Determinant of Cost of Financial Intermediation in Nigeria's Preconsolidated Banking Sector”, Department of Accounting Ahmadu Bello University, Zaria, Nigeria.

M. K. Dash, 2010 "The Determinants of Non-Performing Assets in Indian Commercial Bank: An Econometric Study".

Mishkin, Frederic S. and Stanley G. Eakins, (2006), “Financial Market \& Institutions”, Fifth Edition, New York :Peaerson, Addison Wesley

Odedokun, M.O. (1998), "Financial intermediation and economic growth in developing countries", Journal of Economic Studies, Vol. 25 Issue : 3 p. 203 - 224.

Rahman Q. M. (2012), "All about non-performing loan: The Bangladesh scenario".

Rahman, S. (2016), "Three non-banks weigh down entire sector", The Daily Star, August 14, 2016; http://www.thedailystar.net/business/three-non-banks-weigh-down-entire-sector-1269451.

Rajan, R., and Sarat, C. D. (2003), "Non-performing Loans and Terms of Credit of Public Sector Banks in India: An Empirical Assessment", 24(3), 81-121

Saba, I. Kouser, R. and Azeem, M. (2012), "Determinants of Non-Performing Loans: Case of US Banking Sector”, Volume Number 44.

Sinkey, J. F. and Mary B. G. (1991), “Loan-Loss Experience and Risk-Taking Behavior at Large Commercial Banks” Journal of Financial Services Research.

Tracey, M. (2011), "The Impact of Non-performing Loans on Loan Growth: an econometric case study of Jamaica and Trinidad and Tobago".

Wallich, C.I. (2006), "Status of Non-performing Loans in Banking Sector in Bangladesh", $1^{\text {st }}$ Edition.

\section{Appendix1}

\begin{tabular}{|c|c|c|c|c|c|c|c|c|c|c|c|c|}
\hline Sr. No & NBFI & Year & LDR & NIM & $\mathrm{OM}$ & NPM & $\mathrm{ROA}$ & $\mathrm{ROE}$ & NPL & NAV & EPS & $\begin{array}{r}\mathrm{P} / \mathrm{E} \\
\text { Ratio }\end{array}$ \\
\hline \multirow[t]{6}{*}{1} & \multirow[t]{6}{*}{ IDLC } & 2010 & 1.63 & 0.41 & 0.43 & 0.27 & 0.04 & 0.40 & 0.03 & 31.88 & 10.66 & 11.04 \\
\hline & & 2011 & 1.49 & 0.40 & 0.28 & 0.11 & 0.03 & 0.12 & 0.02 & 26.04 & 10.82 & 14.6 \\
\hline & & 2012 & 1.42 & 0.36 & 0.24 & 0.13 & 0.01 & 0.21 & 0.03 & 27.89 & 3.15 & 21.68 \\
\hline & & 2013 & 1.36 & 0.33 & 0.22 & 0.10 & 0.01 & 0.42 & 0.03 & 30.11 & 2.95 & 11.42 \\
\hline & & 2014 & 1.29 & 0.39 & 0.27 & 0.15 & 0.01 & 0.41 & 0.03 & 31.81 & 2.05 & 12.78 \\
\hline & & 2015 & 1.16 & 0.41 & 0.31 & 0.15 & 0.01 & 0.40 & 0.04 & 34.1 & 2.37 & 11.96 \\
\hline \multirow[t]{6}{*}{2} & Uttara & 2010 & 2.43 & 0.25 & 0.71 & 0.49 & 0.02 & 0.27 & 0.02 & 15.24 & 3.67 & 14.61 \\
\hline & \multirow[t]{5}{*}{ Fin } & 2011 & 2.33 & 0.34 & 0.47 & 0.32 & 0.03 & 0.27 & 0.01 & 13.06 & 3.29 & 20.3 \\
\hline & & 2012 & 2.03 & 0.45 & 0.48 & 0.30 & 0.02 & 0.20 & 0.01 & 13.79 & 2.79 & 13.55 \\
\hline & & 2013 & 1.96 & 0.22 & 0.27 & 0.02 & 0.01 & 0.12 & 0.02 & 14.92 & 2.03 & 12.36 \\
\hline & & 2014 & 2.02 & 0.19 & 0.32 & 0.05 & 0.01 & 0.14 & 0.03 & 10.15 & 2.16 & 8.84 \\
\hline & & 2015 & 1.62 & 0.32 & 0.41 & 0.15 & 0.01 & 0.13 & 0.04 & 9.22 & 2.24 & 5.73 \\
\hline \multirow[t]{6}{*}{3} & \multirow[t]{6}{*}{ DBH } & 2010 & 1.43 & 0.17 & 0.37 & 0.14 & 0.02 & 0.32 & 0.02 & 16.49 & 4.42 & 9.65 \\
\hline & & 2011 & 1.63 & 0.33 & 0.33 & 0.16 & 0.02 & 0.32 & 0.02 & 16.79 & 4.59 & 18.68 \\
\hline & & 2012 & 1.53 & 0.28 & 0.24 & 0.11 & 0.02 & 0.21 & 0.03 & 19.99 & 3.04 & 11.79 \\
\hline & & 2013 & 1.26 & 0.34 & 0.29 & 0.13 & 0.01 & 0.07 & 0.06 & 20.69 & 1.31 & 17.48 \\
\hline & & 2014 & 1.18 & 0.37 & 0.31 & 0.15 & 0.01 & 0.11 & 0.06 & 21.07 & 1.91 & 13.22 \\
\hline & & 2015 & 1.17 & 0.39 & 0.32 & 0.18 & 0.01 & 0.14 & 0.05 & 22.1 & 2.91 & 6.96 \\
\hline \multirow[t]{6}{*}{4} & Lanka & 2010 & 2.08 & 0.37 & 0.64 & 0.44 & 0.03 & 0.34 & 0.06 & 31.12 & 4.95 & 13.88 \\
\hline & \multirow[t]{5}{*}{ Bangla } & 2011 & 1.97 & 0.41 & 0.41 & 0.25 & 0.02 & 0.14 & 0.06 & 29.11 & 5.68 & 15.07 \\
\hline & & 2012 & 2.46 & 0.20 & 0.17 & 0.10 & 0.01 & 0.10 & 0.06 & 21.79 & 4.6 & 9.91 \\
\hline & & 2013 & 2.34 & 0.27 & 0.30 & 0.18 & 0.00 & 0.06 & 0.07 & 21.65 & 1.52 & 22.89 \\
\hline & & 2014 & 1.82 & 0.24 & 0.15 & 0.09 & 0.01 & 0.11 & 0.07 & 26.71 & 2.91 & 11.2 \\
\hline & & 2015 & 1.39 & 0.22 & 0.15 & 0.07 & 0.01 & 0.07 & 0.07 & 27.16 & 3.13 & 11.88 \\
\hline \multirow[t]{6}{*}{5} & \multirow[t]{6}{*}{ IPDC } & 2010 & 1.31 & 0.36 & 0.18 & 0.27 & 0.01 & 0.16 & 0.05 & 373.S2 & 4.16 & 17.49 \\
\hline & & 2011 & 1.14 & 0.22 & 0.19 & 0.16 & 0.02 & 0.21 & 0.04 & 29.68 & 4.31 & 23.16 \\
\hline & & 2012 & 1.33 & 0.30 & 0.23 & 0.14 & 0.02 & 0.15 & 0.03 & 35.44 & 3.24 & 16.18 \\
\hline & & 2013 & 1.30 & 0.33 & 0.29 & 0.13 & 0.01 & 0.04 & 0.08 & 28.57 & 1.14 & 23.51 \\
\hline & & 2014 & 1.42 & 0.45 & 0.36 & 0.15 & 0.01 & 0.03 & 0.08 & 26.17 & 0.59 & 34.24 \\
\hline & & 2015 & 1.41 & 0.54 & 0.44 & 0.24 & 0.01 & 0.04 & 0.08 & 26.74 & 2.05 & 11.18 \\
\hline \multirow[t]{5}{*}{6} & United & 2010 & 1.68 & 0.48 & 0.35 & 0.32 & 0.02 & 0.19 & 0.06 & 18.79 & 3.61 & 13.4 \\
\hline & \multirow[t]{4}{*}{ Finance } & 2011 & 1.54 & 0.47 & 0.32 & 0.17 & 0.04 & 0.39 & 0.05 & 18.33 & 4.68 & 16.3 \\
\hline & & 2012 & 1.41 & 0.41 & 0.26 & 0.15 & 0.02 & 0.23 & 0.03 & 19.91 & 4.8 & 9.27 \\
\hline & & 2013 & 1.33 & 0.42 & 0.29 & 0.14 & 0.01 & 0.08 & 0.06 & 18.07 & 1.46 & 16.99 \\
\hline & & 2014 & 1.26 & 0.45 & 0.30 & 0.16 & 0.01 & 0.16 & 0.04 & 21.19 & 3.49 & 5.39 \\
\hline
\end{tabular}




\begin{tabular}{|c|c|c|c|c|c|c|c|c|c|c|c|c|}
\hline & & 2014 & 1.26 & 0.45 & 0.30 & 0.16 & 0.01 & 0.08 & 0.06 & 22.82 & 3.69 & 5.45 \\
\hline \multirow[t]{6}{*}{7} & National & 2010 & 1.42 & 0.41 & 0.40 & 0.24 & 0.02 & 0.20 & 0.03 & 21.75 & 5.68 & 34.42 \\
\hline & Housing & 2011 & 1.90 & 0.35 & 0.28 & 0.15 & 0.02 & 0.28 & 0.02 & 35 & 10.01 & 22.9 \\
\hline & & 2012 & 1.56 & 0.34 & 0.25 & 0.06 & 0.02 & 0.23 & 0.03 & 44.7 & 10.77 & 14.98 \\
\hline & & 2013 & 1.41 & 0.40 & 0.33 & 0.19 & 0.01 & 0.21 & 0.03 & 54.27 & 11.57 & 10.11 \\
\hline & & 2014 & 1.45 & 0.47 & 0.39 & 0.23 & 0.01 & 0.16 & 0.04 & 63.21 & 10 & 10.47 \\
\hline & & 2015 & 1.32 & 0.50 & 0.42 & 0.22 & 0.02 & 0.23 & 0.03 & 72.59 & 11.03 & 9.59 \\
\hline \multirow[t]{6}{*}{8} & Islamic & 2010 & 1.23 & 0.29 & 0.35 & 0.20 & 0.02 & 0.23 & 0.02 & 28.86 & 4.98 & 12.94 \\
\hline & Finance & 2011 & 1.29 & 0.32 & 0.27 & 0.04 & 0.03 & 0.25 & 0.02 & 26.74 & 5.49 & 23.57 \\
\hline & & 2012 & 1.49 & 0.37 & 0.25 & 0.13 & 0.03 & 0.19 & 0.02 & 23.63 & 4.13 & 15.89 \\
\hline & & 2013 & 1.48 & 0.35 & 0.25 & 0.11 & 0.02 & 0.14 & 0.03 & 28.22 & 3.91 & 8.11 \\
\hline & & 2014 & 1.31 & 0.31 & 0.23 & 0.21 & 0.02 & 0.14 & 0.04 & 30.37 & 4.15 & 7.01 \\
\hline & & 2015 & 1.25 & 0.31 & 0.24 & 0.18 & 0.01 & 0.15 & 0.03 & 33.11 & 3.5 & 7.77 \\
\hline \multirow[t]{6}{*}{9} & Union & 2010 & 1.71 & 0.33 & 0.62 & 0.33 & 0.02 & 0.37 & 0.03 & 14.72 & 3.69 & 10.13 \\
\hline & Capital & 2011 & 1.61 & 0.33 & 0.43 & 0.16 & 0.03 & 0.59 & 0.02 & 13.49 & 3.94 & 15.41 \\
\hline & & 2012 & 1.68 & 0.07 & 0.17 & 0.05 & 0.01 & 0.21 & 0.02 & 13.76 & 1.92 & 14.48 \\
\hline & & 2013 & 1.37 & 0.26 & 0.28 & 0.09 & 0.01 & 0.13 & 0.04 & 14.31 & 1.8 & 11.56 \\
\hline & & 2014 & 1.34 & 1.70 & 0.24 & 0.11 & 0.01 & 0.09 & 0.04 & 15.97 & 1.47 & 8.78 \\
\hline & & 2015 & 1.22 & 1.65 & 0.28 & 0.10 & 0.01 & 0.13 & 0.04 & 17.9 & 1.92 & 6.34 \\
\hline \multirow[t]{6}{*}{10} & Bay & 2010 & 3.06 & 0.09 & 0.75 & 0.54 & 0.01 & 0.12 & 0.02 & 11.32 & 1.29 & 16.93 \\
\hline & Leasing & 2011 & 3.46 & 0.25 & 0.52 & 0.46 & 0.01 & 0.16 & 0.03 & 11.53 & 1.61 & 25.22 \\
\hline & & 2012 & 2.89 & 0.17 & 0.32 & 0.16 & 0.01 & 0.14 & 0.03 & 12.03 & 1.55 & 16.97 \\
\hline & & 2013 & 1.86 & 0.18 & 0.28 & 0.19 & 0.01 & 0.13 & 0.03 & 13.77 & 1.85 & 10 \\
\hline & & 2014 & 1.83 & 0.17 & 0.24 & 0.16 & 0.53 & 0.12 & 0.02 & 15.65 & 1.88 & 8.03 \\
\hline & & 2015 & 1.72 & 0.19 & 0.19 & 0.10 & 0.35 & 0.15 & 0.01 & 20.29 & 1.58 & 6.91 \\
\hline \multirow[t]{6}{*}{11} & Prime & 2010 & 2.32 & 0.32 & 0.68 & 0.56 & -0.11 & 0.56 & 0.81 & -6.68 & -3.1 & 0 \\
\hline & Finance & 2011 & 2.41 & 0.23 & 0.47 & 0.34 & -0.07 & 0.27 & 0.62 & -8.73 & -2.04 & -9.79 \\
\hline & & 2012 & 1.74 & 0.02 & 0.21 & 0.16 & -0.10 & 0.27 & 0.57 & -11.44 & -2.7 & -3.7 \\
\hline & & 2013 & 1.59 & 0.08 & 0.18 & 0.11 & -0.07 & 0.12 & 0.61 & -13.03 & -1.6 & -4.7 \\
\hline & & 2014 & 1.73 & 0.21 & 0.26 & 0.22 & -0.05 & 0.07 & 0.73 & -14.06 & -1.02 & -9.76 \\
\hline & & 2015 & 1.50 & 0.03 & -0.10 & -0.27 & -0.06 & 0.13 & 1.00 & -14.34 & -0.43 & -35.64 \\
\hline \multirow[t]{6}{*}{12} & IIDFC & 2010 & 2.57 & 0.28 & 0.35 & 0.26 & 0.02 & 0.24 & 0.06 & 19.25 & 4.12 & 22.3 \\
\hline & & 2011 & 2.31 & 0.17 & 0.05 & 0.01 & 0.02 & 0.19 & 0.05 & 20.82 & 6.01 & 23.64 \\
\hline & & 2012 & 1.76 & 0.14 & 0.05 & 0.01 & 0.01 & 0.08 & 0.04 & 19.32 & 2.4 & 28.17 \\
\hline & & 2013 & 1.66 & 0.13 & 0.06 & 0.04 & 0.00 & 0.06 & 0.05 & 18.34 & 1.09 & 33.21 \\
\hline & & 2014 & 1.41 & 0.21 & 0.14 & 0.08 & 0.01 & 0.15 & 0.04 & 21.12 & 3.13 & 10.96 \\
\hline & & 2015 & 1.17 & 0.24 & 0.15 & 0.07 & 0.01 & 0.06 & 0.98 & 24.28 & 3.53 & 4.59 \\
\hline
\end{tabular}

